\title{
Electroencephalogram Recording in Garut Sheep: Effect of The Use of Xylazine in Small Ruminants
}

\author{
$\underline{\text { Dian Vidiastuti }}^{1, a^{*}}$, Harry Soehartono ${ }^{2}$, Deni Noviana ${ }^{2}$ \\ ${ }^{1}$ Surgery Labarotory, Faculty of Veterinary Medicine, Brawijaya University \\ ${ }^{2}$ Surgery and Radiology Laboratory, Faculty of Veterinary Medicine, Bogor Agricultural \\ University
}

${ }^{a)}$ Corresponding author: dianvidiastuti@gmail.com

\begin{abstract}
Minor procedures which are not painfull but require the animal to be relatively immobile may be performed with the aid of a sedative. In practical terms, sedative agent cause some degree of drowsiness until lost of consciousness. Xylazine used as a sedative and anaesthetic induction by inhibiting the release of norepinephrine in the brain, especially the locus coeruleus. Electroencephalogram (EEG) isa non-invassive procedureto record electrical activity from the scalp surface conduction media using metal electrodes. Garut sheep is an germ plasm asset of West Java and have a good potential to be developed as a source of meat, fighting sheep and laboratory animal in Indonesia. The aim of this study was to determine the condition of the brain electrical activity of Garut sheep by xylazine. Four healthy female Garut sheeps, age of 1-2 years old, 25$35 \mathrm{~kg}$ body weight were used in this studies. They received xylazine bolus injection with a dose of $0.1 \mathrm{mg} / \mathrm{kg}$ body weight. Recording of the brain's electrical conduction was done using EEG. The placement of the electrodes on the head of sheep was performed at the point $\mathrm{FP}_{1}-\mathrm{F}_{7}$ and $\mathrm{FP}_{2}-\mathrm{F}_{2}$. Monitoring was conducted before induced and recording was done continuously starting before, during and after the induction of xylazine. Recorded data was collected for 60 minutes. The results showed that 15 minutes before injection brain waves presented gamma waves $(30-70 \mathrm{~Hz})$.However, one minutes after injection turned into beta waves (13-30 Hz) with a sharp wave morphology. Then 45 minutes later it entered the recovery phase, where the brain waves returned back to the gamma waves. These effect might occur that xylazine affect $\alpha 2$ receptors in locus coeruleus and it is involved the regulation of sleep or wakefulness.
\end{abstract}

Keywords: electroenchepalogram, xylazine, Garut sheep

\section{INTRODUCTION}

Minor procedures which are not painfull but require the animal to be relatively immobile may be performed with the aid of a sedative. In practical terms, sedative agent cause some degree of drowsiness until lost of consciousness and may be used tofacilitate examinations and minor procedures (e.g., blood collection) on small ruminant [1]. Xylazine is $\alpha 2$-adrenoreceptor agonists are working on $\alpha 2$ receptors and is often used as a sedative and anesthetic induction. $\alpha 2$ receptors on the presynaptic initially suspected distributed by a negative feedback mechanism regulating the release of norepinephrine by the noradrenergic neurons [2]. Electroencephalogram (EEG) is electrobiology imaging tool that is widely used in the medical field in a variety of central nervous research. Virtual imaging procedures with EEG non-invasive and can be repeated in patients [3]. In veterinary medicine as well as in scientific investigation sheep are preferred as experimental animal 
because of their unique characteristic features. Among these characteristic their easy and perfect adaptations to laboratory condition [4]. Garut sheep has good potential to be developed as a source of meat and quite responsive the maintenance of good management, compared to the local sheep and other sheep nations in Indonesia. In addition, it has unique advantages which can be used as appeal regional tourism, especially for sheep fighting type [5]. Garut sheep is an germ plasm asset of West Java and have a good potential to be laboratory animal in Indonesia. The aim of this study was to determine the condition of the brain electrical activity of Garut sheep by xylazine

\section{MATERIALS AND METHODE Animal Model}

Four healthy females Garut sheep which have been selected through a physical examination by weight $27-33 \mathrm{~kg}$, productive age and not pregnant. Animals reared in cages in which one cage containing two sheep Animals. Grass feed is given three times a day, additional food is given morning and drinking water ad libitum. Acclimatization is done by giving anthelmintic oxfendazole $5 \mathrm{mg} / \mathrm{kg}$ orally single dose for one day and oxytetracycline injection $6-11 \mathrm{mg} / \mathrm{kg}$ intramuscular single dose once a day. This research has been obtaining approval from animal ethic committee, Faculty of Veterinary Medicine, Bogor Agricultural University.

\section{Anaesthesia Procedures}

Garut sheep that have acclimatized to undergo anesthesia. The day before treatment, the sheep were fasted for about 12 hours and given appropriate treatment group. The sheep hair shaving done for intravenaous (IV) cathether around the saphenous vein anddisposible electrodes placement on the head. Electrode mounting location must be clean of dirt to avoid electrical interference signal receipt. Intravenous cathether size $22 \mathrm{G}$ performed on saphenous vein immediately before treatment, glued with microphore tape and wrapped with elastic bandage. They received xylazine bolus injection with a dose of $0.1 \mathrm{mg} / \mathrm{kg}$ body weight. Xylazine is injected slowly through the saphenous vein. Disposable syringes without needles contain anesthetic mounted on the end plug hole intravenous cathether. Recording the brain's electrical conduction done using Electroencephalogram (Cognionics Mini Data Acquisition System®) for 60 minutes. The placement of the electrodes on the sheep head performed at the point FP1-F7 and FP2-F2 [3][6]. The results of leads transformed EEG signal in graphical form using MATLAB software for Windows 7 (The Mathworks, Inc.).

\section{RESULT AND DISCUSSION}

Sedation is an individual condition of depressed central nervous followed by drowsiness. Patients were not aware of his surroundings but still responds to pain. Class of sedative drugs are classified as follows: phenothiazines (Acepromazine), butyrophenones (azaperone), a2-agonists (xylazine, medetomidine, detomidine, romifidine) and benzodiazepines (diazepam, midazolam). In general, sedation may be used alone or in combination with a general anesthetic and as a premedication in anesthesia induction [7][8].

Electroencephalogram record electrical activity from the scalp surface using conduction media of metal electrode [9]. EEG waves are distinguished by frequency, amplitude and morphology [3]. 


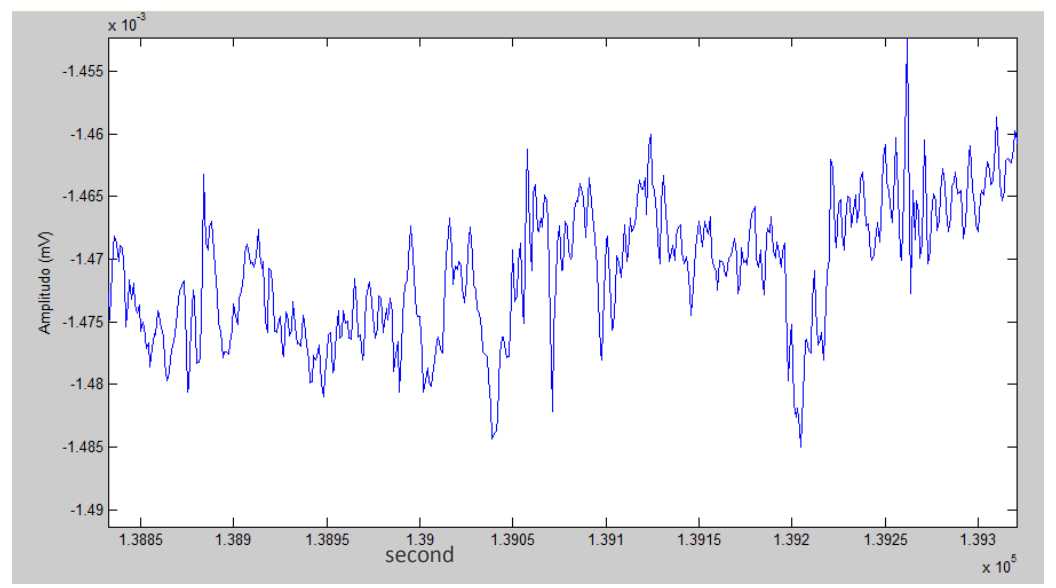

FIGURE 1. Garut sheep brain electroencephalogram beforeinjection with xylazin shows the type of gamma waves

Fig 1 showed that 15 minutes before injection brain waves presented gamma waves $(30-70 \mathrm{~Hz})$. The rhythm EEG brain waves recorded during 100 minutes in pre anesthesia, anesthesia and post anesthesia during treatment. Type of gamma waves looks dominant beforeinjection of xylazine. It showed that sheep still in a state of active and full awareness.

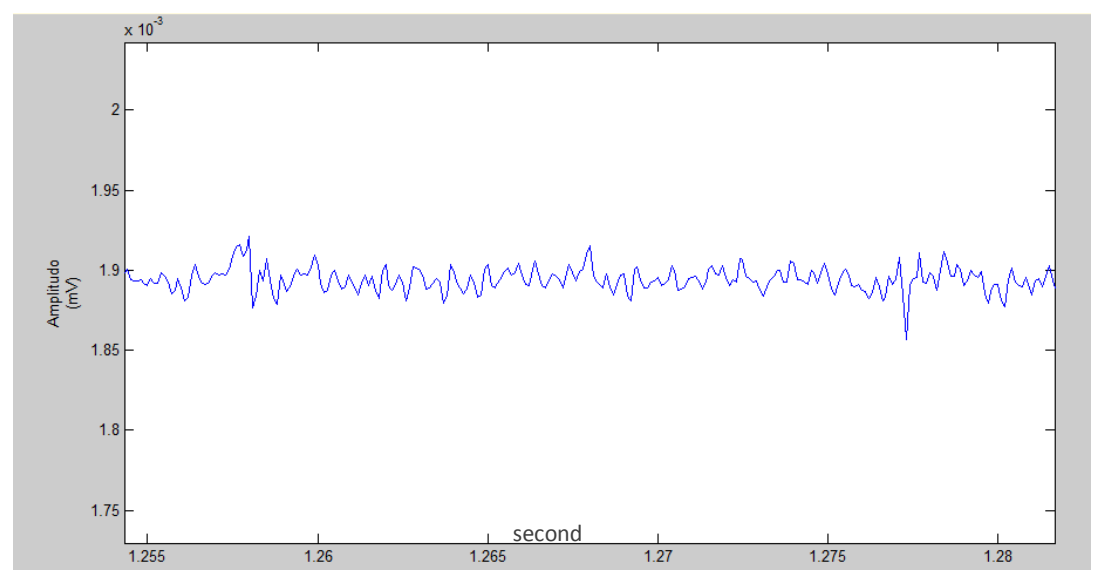

FIGURE 2 Garut sheep brain electroencephalogram as long as injection of xylazine indicates the type of beta waves

However, one minutes after injection turned into beta waves $(13-30 \mathrm{~Hz})$ with a sharp wave morphology (figure 2). Itindicate changes into beta and alpha with a sharp wave morphology. This is consistent with research [10] that xylazine injection increases beta waves rhythm. The type and depth of anesthesia can affect EEG signal response. Sedatives such as xylazine will increase the activity of beta waves [11]. On the condition of the individual to experience relaxation or closed eye condition, the brain will show alpha waves [12]. Then 45 minutes later it entered the recovery phase, where the brain waves returned back to the gamma waves (Figure 3 ). 


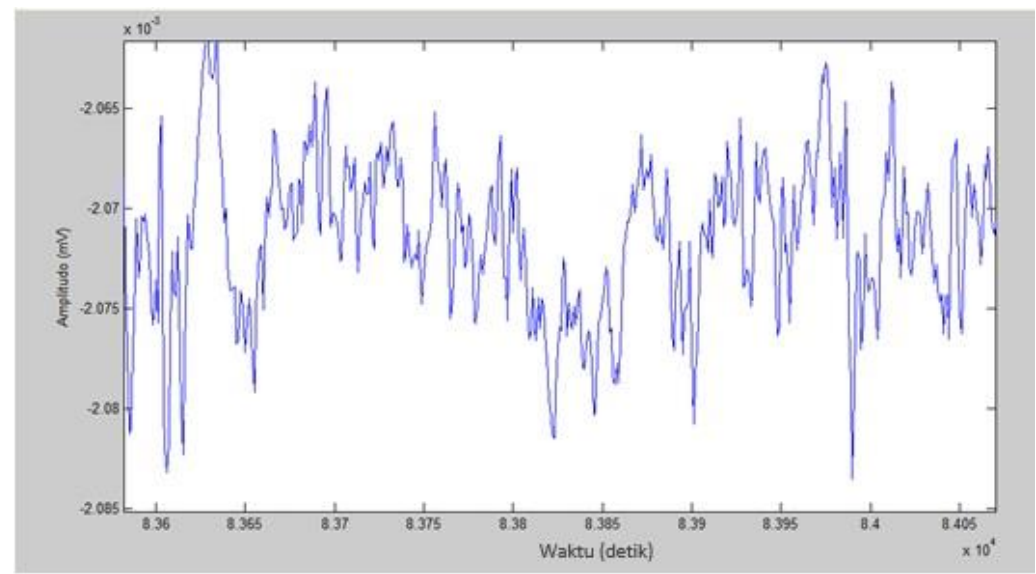

FIGURE 3 Garut sheep brain electroencephalogram post injection with xylazine shows the type of gamma waves

Xylazin inhibiting the release of norepinephrine brain, especially in the locus ceruleus which is located in the posterior pons. Locus ceruleus rich and $\alpha 2$ receptors involved in the regulation of sleep and wakefulness. It is believed that the drug effects of sedative or hypnotic xylazin mediated at the venue. Xylazin low-dose beneficial for reducing anxiety. Xylazin analgesia effect arising from the interaction with the receptor $\alpha 1$. This mechanism is mediated by receptors located in the dorsal horn spinal cord and brainstem [2].Mechanism of action of xylazin as group a2adrenoreceptor agonists $\alpha 2$ binds to receptors located on sympathetic nerve terminals andinhibiting the release of norepinephrine [13]

\section{CONCLUSION}

A single injection of xylazine in Garut sheep affect brain wave signals which was originally gamma type into beta waves without cause deep sedation.

\section{AKNOWLODGEMENT}

The author would like to thank Drh Amrozi PhD on support for research animal facility

\section{References}

1. M.J. Allen and G.L. Borkowski. The Laboratory Small Ruminant. CRC Press, Florida 1999), pp. 89

2. B. Pypendop, "Alpha 2 adrenoceptor agonists in dogs and cats", Proceeding In: 50th CongressoNazionaleMultisala SCIVAC, Rimini, Italia. http://www.ivis.org, (2005)

3. M. Teplan, "Fundamentals of EEG Measurement" MeasSci Rev 2 (2):1-10 (2002)

4. F, Özkan, N. C. Özkan, A. Eyibilen, T.Yener and Ü. Erkorkmaz, "Comparison of KetamineDiazepam with ketamine-Xylazine Anesthethic Combination in Sheep Spontaniously Breathing and Undergoing Maxillofacial Surgery", Bosnian Journal Of Basic Medical Sciences; 10 (4): 297-302 (2010) 
D. HeriyadiHeriyadi, D.dan M. Rukmitasari, 'Sertifikasi Bibit Domba Garut, Laporan Penelitian, KerjasamaDinas Peternakan Provinsi Jawa Barat denganHimpunan Peternak Domba dan KambingIndonesia (HPDKI) Jawa Barat" in "Identifikasi Sifat-sifat Kualitatif Domba Garut Jantan Tipe Tangkas (Qualitative Traits Identification of Bantam Type GarutRam)", J Ilmu ternak $5: 2$ pp. 47-52 (2005)

5. M. Avidan . Reading your mind: monitoring the brain under anaesthesia, in Review Course Lectures. International Anaesthesia Research Society (2012)

6. W. J.Tranquilli, J. C.Thurmon, and K.A. Grimm, Lumb and Jones Veterinary Anaesthesia and Analgesia. (Blackwell Publishing, UK, 2007)

7. R. Bednarski, K. Grimm, R. Harvey, V. M. Lukasik, W. S. Penn, B. Sargent, and K.Spelts (2011) "AAHA Anesthesia Guidelines for Dogs and Cats", American Animal Hospital Association, $47: 6$, pp. 377-385 (2011)

8. E Niedenmeyer and F.H. Lopes da Silva,"Electroencephalography : Basic Principles, Clinical Applications and Related fields", 3rd ed.,(Lippincott, Williams and Wilkins, Philadelphia, 1993).

9. Cwynar P and Zawadzki W, "Recording of bioelectricsl activity changes in sheep cerebral cortex", Arch Med Vet. 42:51-62 (2010)

10. J. C Murreland C.B Johnson,"Neurophysiological technique to asses pain in animals",PharmacolExpTher. 29: 325-335 (2006)

11. R. Sucholeiki, “Normal eeg waveforms",http://www.emedicine.medscape.com(2014)

12. R. E Klabunde, "Cardiovascular pharmacology concept : Alpha-Adrenoceptor Agonists ( $\alpha$ agonists)”, http://www.cvpharmacology.com/ (2013) 